\title{
University of Pittsburgh and FETC CRADA PC96-004, Final Report
}

February 1, 1999

U.S. Department of Energy

Federal Energy Technology Center

626 Cochrans Mills Road

Pittsburgh, PA 15236

and

University of Pittsburgh

350 Thackeray Hall

Pittsburgh, PA 15260

RECEIVED

FFR $>61999$

OSTI 


\section{Disclaimer}

This report was prepared as an account of work sponsored by an agency of the United States Government. Neither the United States Government nor any agency thereof, nor any of their employees, makes any warranty, express or implied, or assumes any legal liability or responsibility for the accuracy, completeness, or usefulness of any information, apparatus, product, or process disclosed, or represents that its use would not infringe privately owned rights. Reference herein to any specific commercial product, process, or service by trade name, trademark, manufacturer, or otherwise does not necessarily constitute or imply its endorsement, recommendation, or favoring by the United States Government or any agency thereof. The views and opinions of authors expressed herein do not necessarily state or reflect those of the United States Government or any agency thereof. 


\section{DISCLAIMER}

Portions of this document may be illegible in electronic image products. Images are produced from the best available original document. 
Cellular deposition is a dynamic phenomenon that may involve both adhesion and detachment, as in thrombosis and thromboembolism. Current techniques for assessing the blood compatibility of opaque biomaterials are limited to endpoint analysis of cellular deposition. To investigate temporal changes in deposition multiple trials with varying duration are generally required.

A fiber optic remote microscope (FORM) has been developed which can measure temporal cellular deposition and detachment in whole blood on opaque biomaterials. These measurements are made in an on-line manner, providing temporal resolution without multiple trials. This measurement system was utilized to assess temporal platelet deposition on a series of adsorbed proteins whose interactions with blood have been well documented. Next the FORM was applied to two opaque biomaterials, polished titanium and polished titanium with a diamond-like coating to assess temporal platelet deposition.

In summary we have demonstrated a novel system for assessing the blood compatibility of opaque biomaterials. This system has the potential to be applied to a variety of surfaces including interior surfaces of blood-contacting medical devices. 